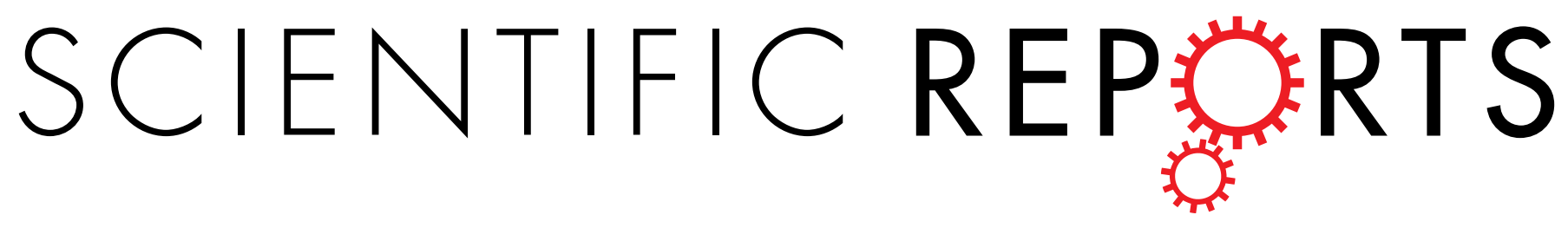

\title{
OPEN Erratum: Insights into functional and evolutionary analysis of carbaryl metabolic pathway from Pseudomonas sp. strain C5pp
}

Vikas D. Trivedi, Pramod Kumar Jangir, Rakesh Sharma \& Prashant S. Phale

Scientific Reports 6:38430; doi: 10.1038/srep38430; published online 07 December 2016; updated on 30 March 2017

This Article contains an error in Figure 1, where panel A is a duplication of panel B. The correct Figure appears below; the Figure legend is correct in the published version.

A

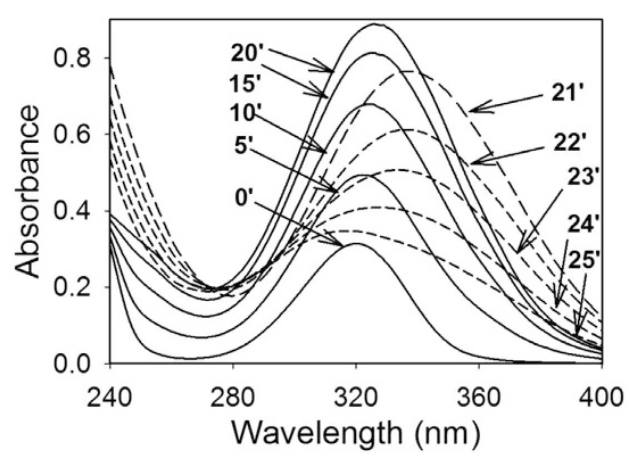

B

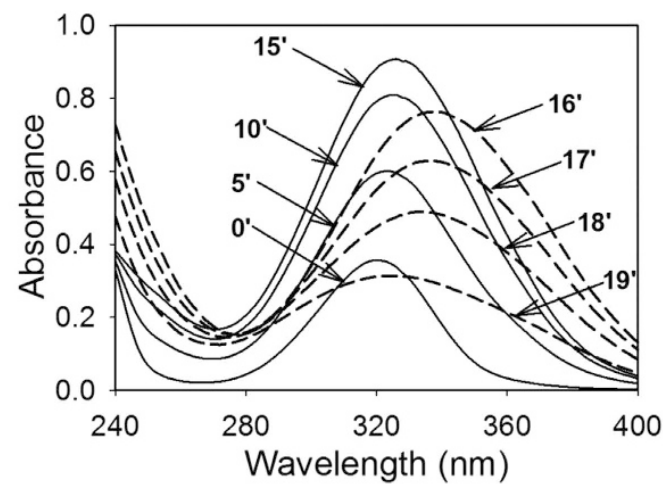

Figure 1.

(i) This work is licensed under a Creative Commons Attribution 4.0 International License. The images or other third party material in this article are included in the article's Creative Commons license, unless indicated otherwise in the credit line; if the material is not included under the Creative Commons license, users will need to obtain permission from the license holder to reproduce the material. To view a copy of this license, visit http://creativecommons.org/licenses/by/4.0/

(C) The Author(s) 2017 